\title{
Eight-month contracts for Oakland University librarians
}

\author{
By Janet Krompart \\ Collection Development Coordinator \\ Oakland University
}

and Richard L. Pettengill

Reference/Collection Development Librarian

Oakland University

\section{Collective bargaining achieves equity for librarians.}

akland University is a medium-sized, statesupported institution in Rochester, Michigan. Beginning with the 1990/91 academic year librarians at Oakland have the same academic year calendar as do members of the teaching faculty. This new schedule, without reduction in pay, was established by a provision in the current collective bargaining agreement between Oakland University and the Oakland Chapter of the American Association of University Professors (AAUP).

This calendar has been a long-time objective of Oakland librarians, and its implementation continues to involve as much careful study and planning as its achievement did.

\section{Background}

Librarians at Oakland were granted faculty status by the Board of Trustees after approval of a constitution for the library faculty by the University Senate in 1970. At that time, Oakland librarians gained many faculty status provisions (the right to form a governance unit; faculty, i.e., professorial ranks; sabbatical leaves; access to research funds), but they remained on the twelve-month contract.

Also in 1970 the Oakland Chapter of AAUP became certified as a collective bargaining unit. As an organized faculty group the librarians no longer could remain in the administrative professional association where they had been members since the founding of the university. The AAUP, however, welcomed librarians, who then became part of the newly formed collective bargaining unit.

In 1973 an arbitrator granted librarians a limited number of "professional development leaves" as an opportunity to show how they might, with this release time, add to their credentials and contribute to scholarship and as a possible interim step toward schedules more like those of the teaching faculty. A number of librarians took advantage of these leaves, which were awarded by a committee of administrators, teachers and librarians.

In 1977 the professional development leaves were ended and librarians gained ten-month schedules through the Oakland University and Oakland Chapter of the AAUP collective bargaining agreement. These schedules consisted of Fall and Winter terms as well as either a Spring or a Summer term. Of course, teaching faculty retained their traditional eight-month, Fall/Winter terms schedule.

Although equity for librarians was urged by the AAUP negotiating teams in other bargaining years (to date these have occurred triennially), it was not until the 1988 sessions that schedule equity was achieved. 


\section{Factors leading to eight-month contracts}

This is a difficult question to answer in any scientific way. These are some of the major factors Oakland librarians believe led to achieving their very long-term goal.

1. Time. From the time Oakland librarians received nominal faculty status to the implementation of the new schedule is almost twenty years. Some may feel that if we knew then what we know now this period should have been shorter, but no doubt this change could not have been realized quickly, at least not during these intervening years.

2. And, of course, the time had to be used to good effect. Looking back on what was basically a learnas-you-go process, these efforts stand out:

a. Librarians paid their dues in the university as well as the bargaining unit and demonstrated professional growth. The concept that second-class citizens must prove themselves before they can advance is not always welcome, but it contains an unavoidable truth.

In this case, librarian service to the university and the AAUP was constant and grew to a level where librarians served on important university committees, including the Senate Steering Committee and the University Research Committee. They even chaired university policy and planning committees and the university-level Faculty Committee on Appointment and Promotion.

Librarians have held a number of offices in the local AAUP chapter as well as the State Conference and proved that a librarian can garner substantial votes for the office of AAUP chapter president. During the two strikes the union has mounted since 1970 , every librarian was on the picket line and several had organizational responsibilities in the strike effort.

Beyond the university, librarians' professional products included not only publication and other scholarly activities but substantial service at the state and national levels, consultantships and other contributions to librarianship and other academic disciplines.

b. Another important activity was keeping librarians' issues, consistently and reasonably presented, before the university and the AAUP, often with considerable documentation on, for example, the library profession's support for adequate compensation for librarians.

3. The final critical factor was the coming together of strategy and luck in the 1988 bargaining sessions.

a. There was the usual presentation of the librarian objectives made by a librarian at the AAUP prebargaining negotiating issues sessions.

b. One fortunate circumstance was the simultaneous presentation of the second-class status concerns of other academic groups. These included continuing part-time teachers, who received only term-length contracts, and those faculty in disciplines, chiefly the humanities, whose pay level had fallen behind that of high-market-value professional disciplines. Combining the appeals of several groups for equity strengthened the arguments of all.

c. And, finally, the 1988 AAUP chief negotiator was highly skilled and both packaged and presented issues well. He was sympathetic to the concerns of second-class groups and mindful of the danger that underdog status for some presents to the solidarity of the collective bargaining unit. Also, he was backed by a top-notch team that included a librarian with expertise in fringe benefit and retirement issues.

\section{Advantages, disadvantages, and implementation plans}

1. Of the possible disadvantages, the availability of fewer librarians on-site to staff library programs, particularly during Spring and Summer, is of the greatest concern. No matter how much Oakland librarians believe that service and scholarship activities contribute to the long-term quality of library service, in the immediate future everyone is concerned about the adequacy of day-to-day support for ongoing library programs.

To address this problem in both the library and the classroom, the contract allows "displacement scheduling" of librarians or teaching faculty. This option makes it possible for the library administration to schedule a few of the library faculty members in Spring and Summer, with either Fall or Winter term off-site, and thus cover the months outside the normal academic year. Hiring of parttime or temporary library faculty or scheduling current faculty for a Spring or Summer term with added compensation are also options. With this selection of options, the library administration currently plans librarian scheduling balanced over the full-year calendar with staffing close to what we now have.

Most clerical-technical staff members at Oakland are directly supervised by administrative professionals, and the impact of shifts in librarian schedules is, therefore, moderated. In any case, all librarian functions are covered by librarians over the twelve months of the year with only two different librarians holding any one assignment in most cases.

2. There is still one hurdle which librarians have that other faculty do not: the faculty agreement provides for a study committee which will recommend to the university "the obligations and standards for scholarly productivity on the part of the library faculty resulting from this change in schedule." The committee, which recently began its 
deliberations, is composed of the associate provost, a member of the teaching faculty, a full professor from the library, the librarian who is chair of the Library Committee on Appointment and Promotion (LCAP) and the dean of the library, ex officio.

Prior to the formation of the committee, library faculty members discussed their views and plans for the newly available release time in order to be able to present their position to the committee rather than wait for the committee's decisions to be imposed. The LCAP has canvassed librarians to determine their plans for the off-site term and will make this information available to the study committee if it is requested.

LCAP also is reviewing current scholarship criteria for reemployment, tenure and promotion of librarians. Heretofore, scholarship criteria have been difficult for librarians on twelve- and tenmonth contracts to meet, so it is important not to assume they need to be more stringent on the new schedule. However, there are aspects of current criteria and procedures that need reevaluation. One example is elimination of the possibility of tenure at the level of assistant professor, which currently is a contractual option for librarians and nurses.

3. An obvious advantage of the new schedule is the additional release time for librarians to grow professionally and the consequent enrichment of library programs. After librarians were awarded faculty status in 1970, their service to the university and to the Oakland Chapter of the AAUP increased and dramatically furthered the integration of the library and its faculty with the university.

The literature on organizational excellence emphasizes the value of professional growth. The opportunity, for example, for librarians to read and do studies in their job assignment subjects (reference, cataloging) has an obvious and direct advantage for library programs. Since research is an essential business of academic libraries, it is also reasonable to expect that librarian research in subject disciplines will support excellence in library service. Librarians who do what their clientele do have an opportunity to achieve not only their own research goals but to gain a stronger perspective on subject collections and other needs of library researchers.

\section{Conclusion}

The change to an eight-month schedule for librarians at Oakland University was intimately involved with the 1971 ACRL Standards and collective bargaining. In achieving this long-term objective, however, Oakland librarians were more committed to librarian working conditions in relation to excellence in library programs and to librarians professional growth than to faculty status as a con- cept. Nevertheless, almost two decades of faculty status as the goal of the profession and the fact that faculty status standards are familiar to teaching faculty colleagues gave this option an edge that no set of locally-devised working conditions could match, and no other goal was considered seriously.

Regarding collective bargaining as a route for librarians, Oakland librarians can speak from a single experience only. The literature generally indicates that collective bargaining is not necessarily a strong factor in improving librarian working conditions. At Oakland, however, it supplied a clear process for presenting issues and kept them open and negotiable in a way that more traditional environments probably would not; thus collective bargaining fit at least one place and time.

In sum, librarians at Oakland University agree that what they have achieved is not a piece of perfection but something, at last, that affords them an equal opportunity to pursue professional goals. The rest is up to each librarian.

\section{ACRL/BIS Midwinter Forum}

Building on the theme of its successful 1990 Midwinter Forum, the ACRL/BIS Continuing Education Committee announces its second annual Midwinter Forum, "Partnerships: The Key to Literacy?" The forum, which will take place on Sunday, January 13, 1991, will feature three speakers addressing needs assessment, curriculum planning, and teacher training as prerequisites for forming partnerships between librarians and instructors. At the conclusion of the speakers' remarks, the audience will be invited to participate in the discussion. Check your Midwinter Conference program for further details concerning the forum's time and location. Please join us with your questions and opinions on this timely topic.

Background reading on the topic can be found in the following:

Beverly T. Watkins, "Schools and Colleges Seen Failing to Form Close Partnerships," Chronicle of Higher Education 35, no.27 (March 15, 1989): A1, A15.

Beverly T. Watkins, "On California State U. Campuses, Everyone Is Responsible for Educating Teachers," Chronicle of Higher Education 36, no.8 (October 25, 1989): A13-15.

Barbara B. Moran, "Library/Classroom Partnerships for the 1990's," C $\mho R L$ News 51 (June 1990): 511-14.

D.J. Smith, "An Examination of Higher Education: A View from the College Library," Journal of Academic Librarianship 15 (July 1989): $140-46$ 